University for Business and Technology in Kosovo

UBT Knowledge Center

Theses and Dissertations

Student Work

Summer 8-20-2020

\title{
Cilësia e mishit dhe produkteve të tij nga këndvështrimi i konsumatorit në Kosovë
}

\author{
Laureta Beqiri \\ University for Business and Technology - UBT
}

Follow this and additional works at: https://knowledgecenter.ubt-uni.net/etd

Part of the Food Science Commons

\section{Recommended Citation}

Beqiri, Laureta, "Cilësia e mishit dhe produkteve të tij nga këndvështrimi i konsumatorit në Kosovë" (2020). Theses and Dissertations. 21.

https://knowledgecenter.ubt-uni.net/etd/21

This Thesis is brought to you for free and open access by the Student Work at UBT Knowledge Center. It has been accepted for inclusion in Theses and Dissertations by an authorized administrator of UBT Knowledge Center. For more information, please contact knowledge.center@ubt-uni.net. 


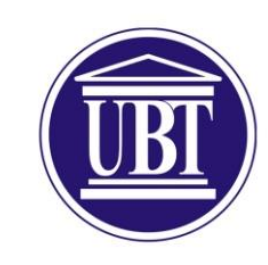

Kolegji UBT

Fakulteti: Shkencat e Ushqimit dhe Bioteknologji

Specializimi: Teknologji Ushqimore

\section{CILËSIA E MISHIT DHE PRODUKTEVE TË TIJ NGA KËNDVËSHTRIMI I KONSUMATORIT NË KOSOVË}

Shkalla Bachelor

Laureta Beqiri

Gusht/ 2020

Prishtinë 


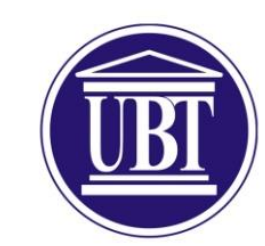

\begin{abstract}
Kolegji UBT
Fakulteti:Shkencat e Ushqimit dhe Bioteknologji

Specializimi: Teknologji ushqimore
\end{abstract}

Punim Diplome

Viti akademik 2017-2018

Laureta Beqiri

\title{
CILËSIA E MISHIT DHE PRODUKTEVE TË TIJ NGA KËNDVËSHTRIMI I KONSUMATORIT NË KOSOVË
}

Mentori: Dr.sc.Hyrije Koraqi

Gusht / 2020

Ky punim është përpiluar dhe dorëzuar në përmbushjen e kërkesave të pjesshme për Shkallën Bachelor 


\section{ABSTRAKT}

Mishi dhe produktet e tij janë pothuajse pjesë e pandashme e dietës sonë. Mishi luan një rol shumë të rëndësishëm duke kontribuar me proteina cilësore,minerale, dhe një sërë vitaminash. Në këtë punim do të shpjegojmë ndërtimin e mishit, vlerat ushqyese, mënyrat e ruajtjes, procesin teknologik të përpunimit dhe ambalazhimit të prodhimeve të mishit, dhe poashtu do të paraqiten rezultatet e hulumtimit të bërë me anë të anketës mbi përdorimin, preferencat, dhe njurive të konsumatorve për prodhimet e mishit.

Përpunimi përfshin marrjen e mishit në formën e tij të papërpunuar dhe shndërrimin e tij në një produkt që është i tregtueshëm, i sigurt për konsum, dhe tërheqës për konsumatorët. Kurse paketimin do të trajtohet si në bazë të llojeve të paketimeve dhe teknologjisë së përdorur, ashtu edhe në bazë të materialit që përdoret për paketim.

Hulumtimi është realizuar përmes anketës online, të anketuarit përfshijn pothuajse të gjitha rajonet e Kosovës. Qëllimi i këtij hulumtimi ishte që të krijojmë një njohuri bazë mbi konsumin e produkteve të mishit në Kosovë, trendin e të ushqyerit, dhe rëndësis që i kushtojnë etiketimit, datës së skadimit etj.

Rezultatet e hulumtimit janë të punuara në programin MS Excel. 


\section{MIR ËNJOHJE/FALENDERIME}

Shprehë mirënjohje dhe falenderim të veçantë për mentoren, Dr.sc.Hyrije KORAQI, për mundin dhe këshillat e pakursyera.

Faleminderit të gjithe Profesorëve dhe Asistentëve për punen e palodhshme gjatë këtyre viteve të studimeve.

Familje dhe Shoqeri, çdo sfidë është më e lehtë me ju, përjetësisht mirnjohëse për përkrahjen dhe kujdesin gjatë rrugëtimit tim. 


\section{PËRMBAJTJA}

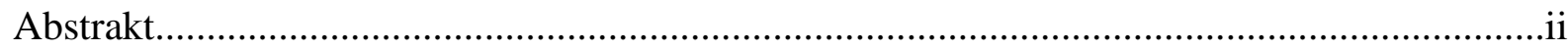

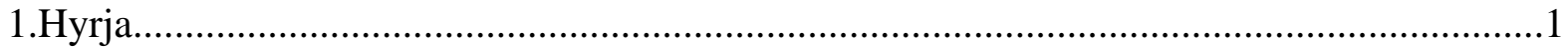

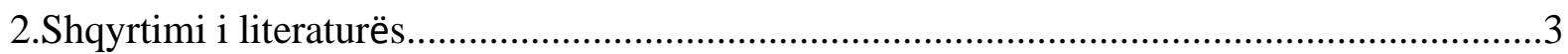

2.1.Njohuri të përgjithshme për mishin...............................................................................

2.1.1.Llojet e produkteve të mishit.......................................................................................

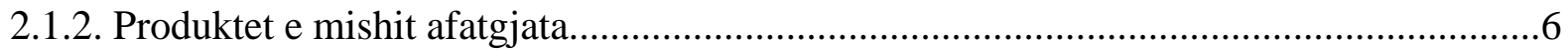

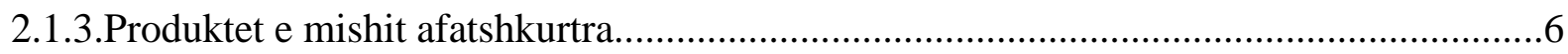

2.1.4.Produktet e mishit të prishura lehtë...............................................................................6

2.1.5.Konzervat e mishit....................................................................................................6

2.1.6.Klasifikimi i mishit bazuar në aw dhe $\mathbf{p}^{\mathbf{H}}$ të produktit....................................................

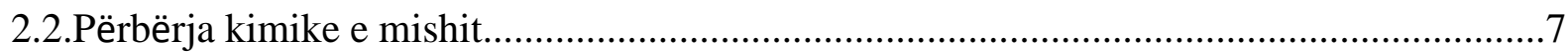

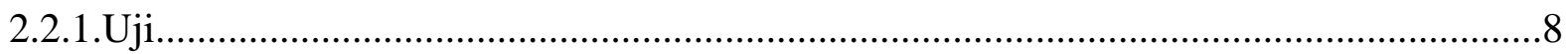

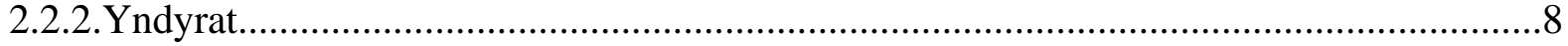

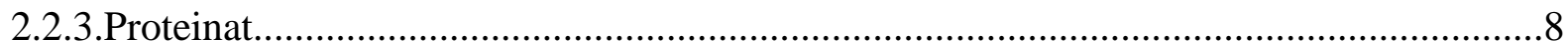

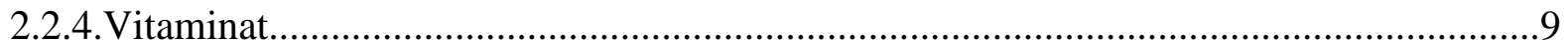

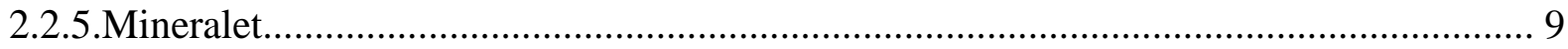

2.3.Përbërja ushqyese e mishit të organeve............................................................................9

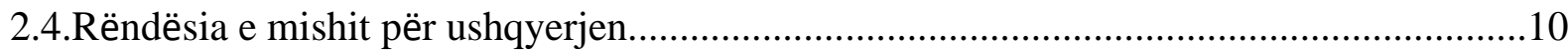

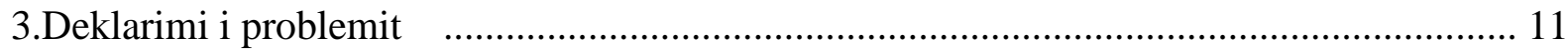

3.1.Procesi teknologjik i prodhimit të produkteve të mishit......................................................11

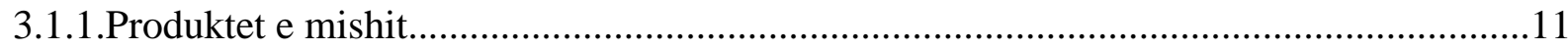

3.1.2.Mjetet e nevojshme për përpunimin e mishit............................................................12

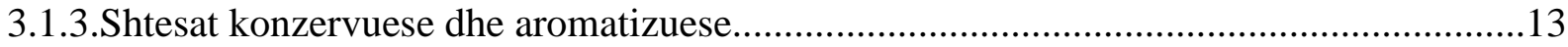

3.2.Ambalazhimi i produkteve të mishit.................................................................................17

3.2.1.Llojet e ambalazhimit të produkteve të mishit............................................................18

3.2.2.Kushtet që duhet të plotësoi materiali për ambalazhim.................................................19

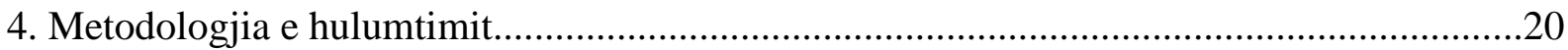




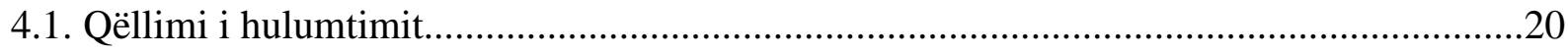

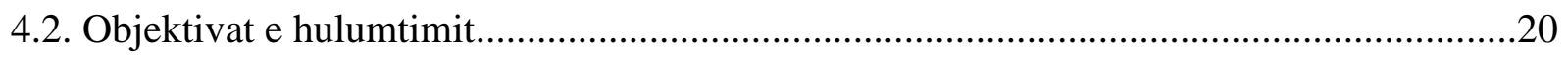

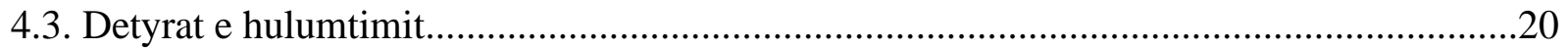

4.4. Metodat, teknikat dhe instrumentet e hulumtimit.....................................................20

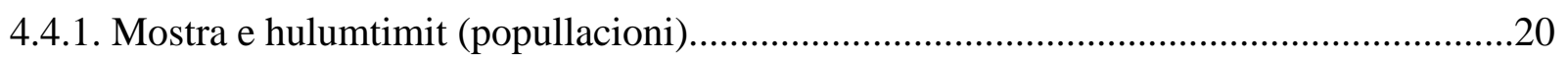

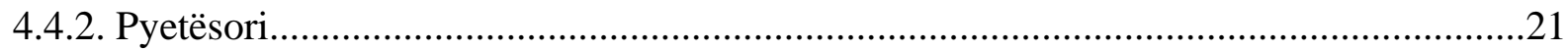

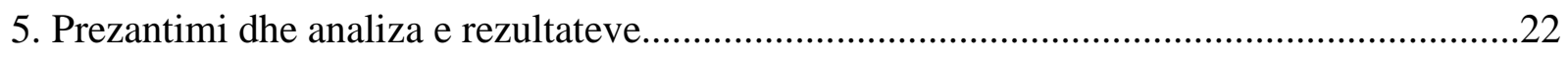

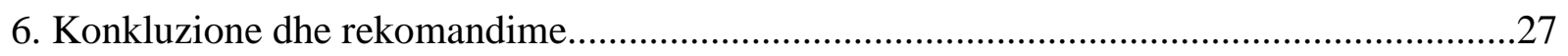

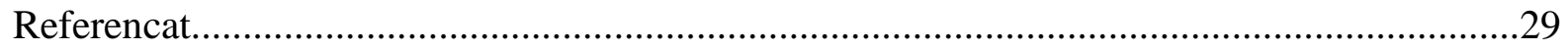




\section{LISTA E FIGURAVE}

Figura 2.1 Seleksionimimi i lëndës së parë për përpunimin e produkteve të mishit..............3

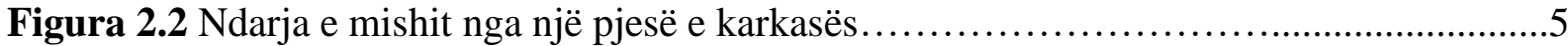

Figura 3.1 Paisjet bazë për punimin e mishit $\quad$.........................................12

Figura 3.2 Kulturat starter....................................................................... 16

Figura 3.3 Produkte të ambalazhuara të mishit..........................................................17 


\section{LISTA E TABELAVE}

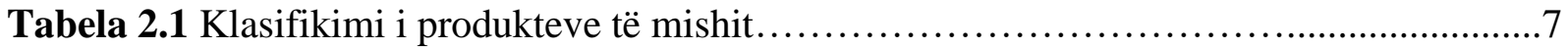




\section{HYRJE}

Zakonisht, produktet e mishit përcaktohen si ushqime që përbëhen ose përmbajnë mish.Mishi i një kafshe, tipike ose shpezëve, konsiderohet si mish (Laranjo et al.2017). Ushqimet janë mjete të rëndësishme dhe të përshtatshme për njeriun për të përcjellin lëndët ushqyese thelbësore që mund të përmirësojnë shëndetin e tyre. Mishi i kafshëve ka një vlerë të lartë biologjike dhe një burim i mirë i proteina në shumë vende. Mishi dhe produktet e mishit janë burime ideale të mineraleve të tretshëm, vitaminave, yndyrave thelbësore, aminoacideve dhe shumë ushqyesve të tjerë që kanë një funksion specifik për trupin (Biesalski, 2005). Mishi është një burim i mirë i acideve yndyrore omega-3, proteinave, vitaminës $B_{12}$ dhe nivele të larta të hekurit (Bender,1992).

Mishi dhe produktet e mishit janë ushqime të rëndësishme me përbërës thelbësorë ushqyes si aminoacidet thelbësore, acidet yndyrore, vitaminat dhe mineralet që formojnë një përbërës të rëndësishëm për proceset normale fiziologjike dhe biokimike dhe kanë një rol të rëndësishëm në përmbushjen dhe mirëmbajtjen të shëndetit të njeriut. Studimet tregojnë se vlerat e larta ushqyese (yndyrna, proteina dhe karbohidratet),minerale, vitamina dhe komponime të tjera funksionale kanë një rol parandalues kundër sëmundjeve të ndryshme të shkaktuara nga mungesës së lëndëve ushqyesve.Mishi si përbërs ushqimor duhet të përfshihet si proporcion i rëndësishëm në dietën e ekuilibruar për të përmbushur përfitimet e kërkuara shëndetësore. Proteinat dhe amino acidet janë të dobishme për rritjen dhe ndërtimin e muskujve te njerëzit (Ahmad et al.2018). Ka një kërkesë në rritje për mish dhe produkte mishi më të shëndetshëm që përmbajnë nivele të ulëta yndyre, kolesterol, përmbajtje të zvogëluar të klorur natriumi dhe nitrite, profil i azhurnuar i acideve yndyrore përbërjen dhe përbërësit e shtuar shëndetësor në mesin e konsumatorët në të gjithë botën.

Kohët e fundit, ekziston një shqetësim në rritje për produktet funksionale të mishit të orientuara nga shëndeti, si rezultat i pengesave të përfshira në ushqimet e muskujve dhe rreziqet e tij të lidhura me shëndetin (Kumar et al.2010). Pengesa kryesore e mishit dhe produkteve të mishit është mungesa e fibrave dietike dhe prania e yndyrës së ngopur. Përmirësimi i vlerës mund të bëhet me përfshirjen e përbërës funksionalë në produktet e mishit. Përdorimi i përbërësve funksional në produktet e mishit $\mathrm{u}$ jep përpunuesve mundësinë për të rritur vlerën funksionale dhe ushqyese të produkteve të tyre. 
Mishi dhe produktet e mishit mund të modifikohen me shtimin e disa përbërësëve që eleminojnë ose zvogëlojnë përbërësit e dëmshëm nga trupi dhe kështu janë të dobishëm për shëndetin. Produktet e mishit të përfshira me fibra dietike janë zëvendësuesit më të mirë të mishit për shkak të vlerave të tyre funksionale dhe ushqyese si shtesa fibroze në mish mund të përdoren: proteinat e perimeve, fibrat dietike, nënprodukte të drithërave, frutat, bishtajoret, erëzat, barishtet dhe acidet laktike që janë përdorur vetëm ose në kombinim për përmirësimin e vlerës funksionale të mishit dhe produkteve të mishit (Kumar et al.2010; Kausar et al.2019). Sipas konsumatorit, konsumi i mishit dhe produkteve të mishit është jo i shëndetshëm për shkak të pranisë së kolesterolit, antioksidantë sintetikë; përmbajtja antimikrobike që rezultojnë në disa sëmundje degjenerative dhe yndyrna të ngopura (Serrano et al.2007).

Mishi i përpunuar nënkupton një produkt që përmban jo më pak se $30 \%$ mish, i cili ka kaluar një metodë ruajtjeje tjetër përveç ngrirjes, dhe përfshin mishin e prodhuar dhe mishin e tharë (p.sh. salcice, sallam, mish të konservuar) (Williams 2007). Prodhuesit duhet të kenë aftësinë të plotësojnë pritjet e konsumatorëve, në lidhje me aspektet shqisore, ushqyese dhe sigurinë, duke marrë parasysh që ata janë gjithnjë e më kërkues dhe më të informuar, duke e kthyer këtë në një sfidë të rëndësishme. 


\section{SHQYRTIMI I LITERATURËS}

\subsection{NJOHURI TË PËRGJITHSHME PËR MISHIN}

Me termin "mish" përkufizohet struktura muskulare dhe indore e: Kafshëve për therrje ( lopë, derra, dhi ); Kafshëve të oborrit (pula, gjela deti, lepuj ); Kafshëve të egra që mund të përdoren për ngrënie.

Mishi është përdorur nga njeriu që në periudhën e antikitetit.Ekonomia tradicionale e tipit gjuetivjelje ka shoqëruar evolucinonin e njeriut për dy milion vjet deri në periudhën e neolitikut, ku gjuetia dhe vjelja u zëvendësuan nga zhvillimi i blegtorisë dhe bujqësisë. Në ditët tona produktet shtazore janë shumë të përhapura në dietat ushqimore të grup-popullatave ekonomikisht të përparuara.

Vlera ushqimore e mishit lidhet me përmbajtjen e aminoacideve kryesore, vitaminave të grupit B, hekurit $(\mathrm{Fe})$ dhe elemneteve të tjerë mineralë. Mishi konsiderohet si një ushqim i vlefshëm proteinik për fëmijët si dhe për të gjitha grupet e popullësisë. Mishi, yndyra dhe pjesët e tjera të karkasës përdoren si lëndë e parë për prodhimin e produkteve të mishit.

Gjatë përpunimit të produkteve të mishit mundë të kërkohet vetëm mish pa u lidhur me indin dhjamor apo indin lidhës, siç ndodhë te përpunimi i proshutës. Ndërsa për disa produkte tjera kërkohet një sasi më e madhe e dhjamit dhe indit lidhës, siç ndodh në përpunimin e sallamës dhe suxhukut. Prandaj hapi i parë i përpunimit të mishit është seleksionimi i lëndës së parë, duke marrë në konsideratë cilësinë e tyre,vlefshmërinë e mishit dhe karkateristikat e mishit të përpunuar. Seleksionimet më të zakonshme të mishit nga karkasa janë: fileto, kondrafileto, bërxollat, pjesa e pasme,pjesët e tjera të qafës dhe të shpatullave (Ranken,2000;Bender,1992;Biesalski, 2005).

Në figurën 2.1 është paraqitur seleksionimi i lëndës së parë për përpunimin e produkteve të mishit. 


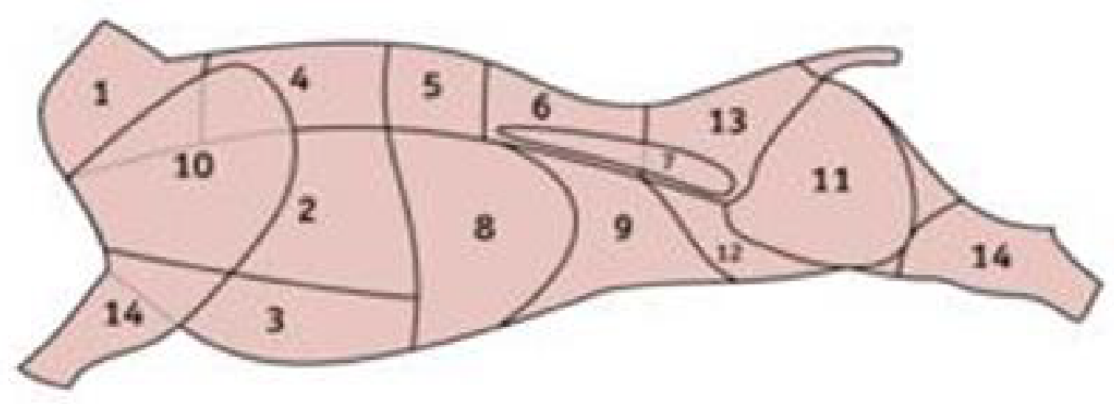

1- Mishi i qafës

2-Rajoni i lakuar i brinjëve

3-Mishi i gjoksit

4- Rajoni i sipërm i brinjëve

5- Bifteku

6- Bifteku i rrafshët

7- Filetë

8-Mishi i rajonit të pasëm të brinjëve

9- Mishi nga rajoni i barkut

10-Mishi i rajonit të shpatullës

11-Mishi i rajonit të kofshës

12- Mishi i krahut

13- Mishi i rajonit të vitheve

14- Mishi i rajonit të këmbëve

Figura 2.1: Seleksionimimi i lëndës së parë për përpunimin e produkteve të mishit.

Duke u bazuar në figurën më lartë mund të tregojmë për disa rajone të karkasës së kafshës, e cila përfshinë pjesë të ndryshme të mishit si lëndë e parë për përpunimin e produkteve të mishit. Rajoni 1- paraqet mishin e qafës me yndyrë 6-8\%, i cili është i pasur me indin lidhës (tendinë). Rajoni i mesëm i brinjëve nga 2-8 së bashku me brinjët ose pa eshtra, është i pasur me dhjam dhe i përshtatshëm për gjellërat në tavë.Rajoni 3- paraqet mishin e gjoksit që ndahet në tri pjesë: pjesa e parme dhe muskuloze (përdoret për zierje dhe është e shtrenjtë); pjesa e gjoksit e pasur me dhjamë (përdoret për zierje); pjesa e pasme me mish që përdoret në supa dhe gjellëra.Rajoni 4paraqet pjesën e sipërme të brinjëve, pjesën e kurrizit që përmban 8-12\% dhjamë në pjesën e përparme dhe 13-17\% në pjesën e pasme. Ajo përdoret për fërgim dhe zierje. Rajonet 5, 6 dhe 7paraqesin pjesën e parme (bifteku i lartë) dhe pjesën e pasme (bifteku i rrafshët), pjesën e brendshme ku gjindet fileta si pjesa më e preferuar e mishit të gjedhit dhe pjesën e përparme me 10\% yndyrë, e cila është mjaftë e përshtatshme për fërgim dhe pjekje (Ranken,2000).

Mishi i rajonit të barkut 9- përfshinë pjesën e çerekut të pasëm që përdoret për zierje dhe për përfitimin e lëngut të mishit. Rajoni 10- është mishi i shpatullës që përmbanë më pak dhjamë, por që ka sasi më të lartë të indit lidhës. Kjo pjesë e mishit është më e fortë dhe shitet me një çmim të lartë në treg. Rajoni 11- paraqet mishin e kofshës që është shumë i përshtatshëm për pjekje dhe fërgim. Në pjesën e brendshme të kofshës gjindet një pjesë në formë të kapakut i lidhur me pjesën 
kryesore të indit lidhës. Pjesa e brendshme e mishit pa strukturë të fijëzuar është e përshtatshme për rollatë, gullash,etj. Rajoni 12- paraqet mishin e vithev, i cili është shumë i përshtatshëm si stek dhe nuk preferohet për zierje për shkak të vlerës së tij të lartë. Rajoni 13- është pjesa e shpatullës dhe e kofshës. Ky mish është i përshtatshëm për fërgim, zierje dhe kërkon kohë më të gjatë për përftimin e mishit të njom. Ndërsa pjesa e fundit e karkasmës përfshinë rajonin 14- mishin e këmbëve dhe një pjesë të vogël të kofshës, e cila është shumë e kërkuar në tregun e restoranteve. Gjithashtu, duhet të theksohet se në përzgjedhjen e pjesëve të mishit të karkasës ndikonë edhe mosha e kafshëve. Kafshët e reja në moshë përmbajnë një kapacitet më të madhë të lidhjes së ujit në krahasim me kafshët më të vjetra në moshë. Prandaj mishi i kafshëve më të vjetra në moshë që kanë kapacitetit më të ulët të lidhjes së ujit përdoren për produktet që i nënshtrohen tharjes dhe fermentimit (Ranken,2000).

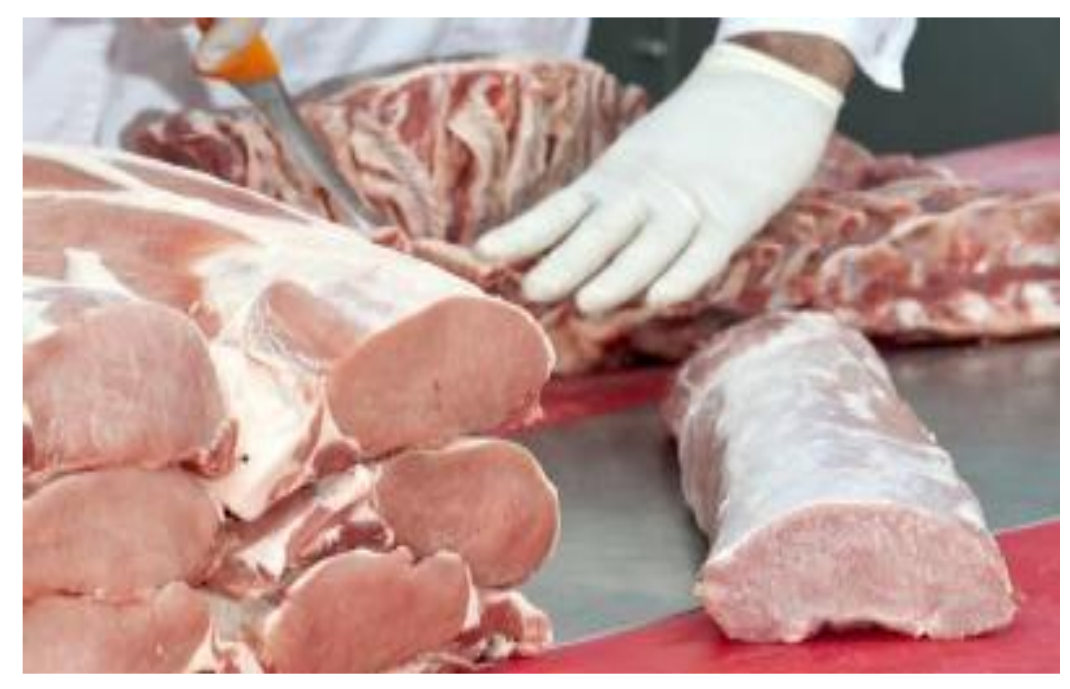

Figura 2.2. Ndarja e mishit nga një pjesë e karkasës.

\subsubsection{LLOJET E PRODUKTEVE TE MISHIT}

Industria e mishit përfshin një prodhim të gjerë me produkte të ndryshme të mishit.

Produktet e mishit të përpunuara ndahen në disa lloje:

1. Produkte të mishit afatgjata

2. Produkte të mishit afatshkurtëra

3. Produktet e mishit të prishura lehtë

4. Konservat e mishit 


\subsubsection{PRODUKTET E MISHIT AFATGJATA}

Si produkte të mishit afatgjata konsiderohen produktet e tymosura të mishit, të terura ose në një mënyrë tjetër të konservuar, të cilat janë të qëndrueshme për një kohë të gjatë pa pasur nevojë të ruhen në vende të ftohta. Disa nga këto produkte janë: mishi i terur, sallami, suxhuku i hollë, i presuar dhe i terur etj.(Ranken,2000).

\subsubsection{PRODUKTET E MISHIT AFATSHKURTERA}

Si produkte të mishit më afatshkurtëra konsiderohen produktet e tymosura ose të konservuara të mishit, të cilat janë të mbrojtura nga prishja e shpejtë e tyre. Ato ruhen për një kohë të shkurtër, pa pasur nevojë të mbahen në vende të ftohta. Disa nga këto produkte janë: salsiçe të ziera, salsiçe të tymosura, salsiçe të kripura, mish i terur,mish i tymosur etj.(Ranken,2000).

\subsubsection{PRODUKTET E MISHIT TE PRISHURA LEHTE}

Si produkte të mishit me ndjeshmëri të lehtë të prishjes konsiderohen ato produkte të cilat kanë aftësi të vogël të qëndrueshmëris dhe për ta ruajtur gjendjen e tyre të freskët, kanë nevojë për ftohje artificiale. Këto produkte përfshijnë lloje të ndryshme të burgerave (qofte, pleskavica, dyner), suxhuk i pjekur, salsiçe etj.(Ranken,2000).

\subsubsection{KONZERVAT E MISHIT}

Si konserva të mishit konsiderohen produktet e mishit që janë të mbyllura hermetikisht në kanaçe të llamarinës ose në enë tjera stabile, siç janë enët prej qelqi.Konservat e mishit ndahen në dy kategori: konservat e plota dhe gjysmë konservat.Gjysmë konservat, janë produkte ku trajtimi termik nuk është i plotë dhe jetëgjatsia e tyre zgjatë deri në disa muaj. Ndërsa konsevat e plota janë produkte në kuti tek të cilat trajtimi termik garanton asgjësimin e të gjitha mikroorganizmave në produkt.

Konservat ose produktet e ambalazhuara janë produkte, te të cilat zbatohen normat teknike të mëposhtme:

* Ambalazhimi i mbyllur hermetikisht nga ndikimi i lëngjeve, gazeve dhe mikroorganizmave.

* Trajtimi termik i aftë për të shkatërruar ose paralizuar veprimtarin e mikroorganizmave apo toksinave të tyre. 


\subsubsection{KLASIFIKIMI I MISHIT BAZUAR NE aw DHE pH E PRODUKTIT}

Produktet e grupit të parë kanë aw më të vogël se 0.91 dhe $\mathrm{pH}$ më të vogël se 5. Për këto produkte nuk është e nevojshme ftohja, sepse konservimi i tyre siguron ruajtjen nga faktorët dëmtues mikrobik, fizik dhe kimik. Ato të grupit të dytë kanë aw të barabartë ose më të vogël se 0.95 dhe $\mathrm{pH}$ përafërsisht 5.2. Ky grup produktesh konservohet mirë në temperaturën $10^{\circ} \mathrm{C}$. Produktet që i takojnë grupit të tretë karakterizohen nga aw më e lartë se 0.95 dhe $\mathrm{pH}$ më të lartë se 5.2. Këto produkte konservohen mirë në temperaturën $50^{\circ} \mathrm{C}$. Konservat kanë një jetëgjatsi prej tre vite,ndërsa gjysmëkonservat mbahen në mjedise të ftohjes me një jetëgjatsi prej tre muaj.Në tabelën më poshtë është treguar klasifikimi i produkteve të mishit (Ranken,2000).

Tabela 2.1 Klasifikimi i produkteve të mishit.

Qëndrueshmëria e produkteve të mishit

Produktet e mishit afatgjata të pa ftohura më shumë se 1 muaj

Produktet e mishit me aftë të të pa ftohura 2 ditë - 1 javë

kufizuar

Produktet e mishit me të ftohura 1-2 ditë

lehtësi prishjeje

Konservat e mishit

$\begin{array}{lll}\text { Konservat e plota } & \text { të pa ftohura } & \text { deri në } 3 \text { vite } \\ \text { Gjysmë konserva } & \text { të ftohura } & \text { deri në } 3 \text { muaj }\end{array}$

\subsection{PERBERJA KIMIKE E MISHIT}

Përbërja kimike e mishit është pothuajse konstante për një numër të madh të kafshëve,ndryshimi midis tyre qëndron kryesisht në përmbajtjen e yndyrnave. Mishi është një produkt ushqimor mjaft i rëndësishëm për organizmin tonë dhe në përmbajtje të tij gjejm: ujin, proteinat, yndyrnat, lëndët minerale, dhe sasi të vogël të karbohidrateve,aminoacideve, si dhe të vitaminave. Mishi përmban afërsisht $50-74 \%$ ujë, $15-22 \%$ proteina, $2-50 \%$ yndyrna, 0.2 deri në $1 \%$ karbohidrate dhe sasi minimale të materieve minerale, vitaminave dhe substancave tjera (Mestani,2017). 


\subsubsection{UJI}

Uji është komponenti më i rëndësishëm i mishit, i cili përfshinë 75\% të peshës së tij.Përqindja e ujit në mish është e lidhur ngushtë me përqindjen e yndyrës. Gjatë therjes uji largohet në formë piklash, largimi i tepërt i ujit ndikon në uljen e cilësisë së mishit dhe në uljen e peshës specifike të mishit.

\subsubsection{YNDYRNAT}

Yndyrat e mishit i sigurojnë njeriut burim energjie dhe duhet të jenë të pranishme në dietën e njeriut me qëllim që ti plotësoj nevojat e trupit. Ato bëjnë pjesë në trigliceride, kolesterol dhe fosfolipide. Një triglicerid përbëhet nga tre acide yndyrore që janë konsideruar si esenciale për njeriun, si: acidi linoleik dhe arakidionik.

Yndyrnat japin aromën specifike, lëngësinë, shijën si dhe vlerë të lartë kalorike të mishit. Yndyrnat mund të jenë dy llojesh:

1. Yndyra të ngopura

2. Yndyra të pangopura

Yndyra e ngopur ose yndyra e kafshëve përbëhet prej një glicerine me tre acide yndyrore plotësisht të ngopura. Shumica e yndyrave shtazore janë të ngopura dhe në disa raste referohen si yndyrnat e këqija që rrisin kolesterolin dhe rrezikun për shfaqjen e sëmundjeve kardiovaskulare. Këto sëmundje ndodhin për shkakë të tretshmërisë së ulët të këtyre yndyrnave në organizëm. Yndyra e pangopur ose "yndyrnat e mira" ndikojnë në funksionin normal të zemrës dhe në mirëmbajtjen e përgjithshme të organizmit tonë. Prandaj themi se ato asimilohen më lehtë nga organizmi dhe janë më të tretshme se sa yndyrnat e ngopura (Serrano et al.2007; Mestani,2017).

\subsubsection{PROTEINAT}

Proteinat në mish ndodhen në sasi prej 18-23\%. Ato janë elemente ndërtuese dhe të pazëvendësueshme prej substancave tjera ushqyese. Cilësia e proteinave të mishit është e ngjajshme me atë që i nevojitet organizmit për rritjen e indeve. Mishi plotson sasitë kryesore të aminoacideve esenciale, si: lizinën, metioninën, treoninën dhe treptofanin, megjithëse përmbajtja e këtyre aminoacideve në mish është relativisht e ulët. Proteinat kryesore dhe me vlerë të plotë janë: miozina, miogjeni, globulina dhe mioglobulina (Biesalski 2005; Bender,1992). 


\subsubsection{VITAMINAT}

Vitaminat janë lëndë organike, të cilat janë jetike për mbijetesën. Ato konsiderohen gjithashtu edhe si substanca mbrojtëse, rregulluese dhe si përbërës aktiv, sepse i rregullojnë proceset trupore dhe mbrojnë organizmin nga sëmundjet dhe nga shfaqja e mangësive të caktuara. Kështu për shembull, vitaminat janë të nevojshme për zbërthimin, transformimin dhe përdorimin e proteienave, yndyrnave dhe karbohidrateve. Mishi është një burim i rëndësishëm i vitaminës $B_{12}$, duke siguruar më shumë se $2 / 3$ e kërkesës ditore në një shërbim prej $100 \mathrm{~g}$ mish. Gjithashtu një nga organet e kafshës më të pasur me vitamin A është mëlçia, ndërsa nivelet e vitaminës D në mish janë të ulëta dhe shpesh nuk janë të përfshira në të dhënat e përbërjes së mishit. Shkenca e të ushqyerit, vitaminat i ndanë sipas veçorive të tretshmërisë.

Ato ndahen në vitamina të tretshme në yndyrna dhe në vitamna të tretshme në ujë.Vitaminat që treten në yndyrë, janë të varura nga absorbimi i yndyrnave të zorrëve dhe mjaftë të rëndësishme për organizmin tone (Kumar et al.2010; Bender,1992).

\subsubsection{MINERALET}

Mineralet janë substanca inorganike të ushqimit. Ato kryejn funksione të ndryshme për zhvillimin e metabolizmit. Varësisht prej sasisë që ndodhen, ato ndahen në makroelemente dhe në mikroelemente. Funksionet e mineraleve janë të ndryshme dhe ato përfaqësohen nga bakri, kobalti, fosfori, mangani, zinku dhe në sasi më të madhe nga hekuri (në veçanti mëlçia), ndërsa kockat kanë përmbajtje të kalciumit dhe fosforit. Burime të mineraleve janë: produktet e mishit, qumështi, djathi, pemët,perimet dhe produktet e drithërave etj (Mestani,2017).

\subsection{PERBERJA USHQYESE E MISHIT TE ORGANEVE}

Të gjitha mishrat e organeve janë jashtëzakonisht të pasura me vitamina, minerale dhe proteina. Disa nga vlerat ushqyse të këtyre organeve janë:

* Mëlçia është një burim i pasur i hekurit, proteinave, zinkut, riboflavinës,vitaminës A dhe folatit.

* Veshka është e pasur me proteina, tiaminë, riboflavin, hekur, dhe me sasi folati.

* Zemra është një burim i mirë i hekurit dhe zinkut, por jo aq i mirë sa mëlçia dhe veshka.

* Truri dhe palca nuk janë burime shumë të mira të vitaminave ose mineraleve.

* Mëlçia është një burim i pasur me retinol dhe konsumimi i lartë i tyre nuk është i rekomandueshëm në shtatzani (Mestani,2017; Bender, 1992). 


\subsection{RENDESIA E MISHIT PER USHQYERJEN}

Mishi është furrnizues me shumë proteina, po ashtu me vitamina dhe minerale. Me rastin e konsumimit të tepruar të mishit, përbërja e lëndëve ushqyese shtresohet dhe në paraskenë shfaqen lëndë me përmbajtje të acideve yndyrorore të ngopura. Fundja,konsekuenca e gjithë kësaj është shfaqja e rreziqeve të sëmundjeve të zemrës. Prandaj për ta ruajtur më shumë shëndetin, mjekët rekomandojnë ushqim me pak mish (Mestani,2017; Biesalski,2005). 


\section{DEKLARIMI I PROBLEMIT}

\subsection{PROCESI TEKNOLOGJIK I PRODHIMIT TË PRODUKTEVE TE MISHIT}

\subsubsection{PRODUKTET E MISHIT}

Prodhimet e mishit zënë një vend të veçantë në qarkullim dhe njohjen e cilësisë së prodhimeve ushqimore , si përmes përpunimit kompleks të mishit në industri apo familje ku fitohet një gamë shumë e gjerë e prodhimeve të mishit me cilësi të ndryshme, pa të cilat është e pamendueshme të ushqyerit modern, si dhe prodhimet me qëndrueshmëri afatgjate të mishit të cilat ruhen lehtë, ekspozohen dhe shiten me një rrezik të reduktuar të humbjes së peshës ose prishjes, ndërsa cilësia e tyre është shumë e vlerësuar në mesin e konsumatorëve qoftë për konsum të menjëhershëm ose për përpunim të mëtutjeshëm në shtëpi.

Teknologjia e përpunimit të mishit përfshin hapat dhe procedurat të prodhimit të produkteve të mishit nga mishi i papërpunuar. Përbërësit kryesorë për produktet e mishit në radhë të parë janë mishi i muskujve dhe dhjami, por në raste më të rralla dhe në raport më të vogël përdoren edhe inde të tjera si p.sh. organet e brendshme, lëkura dhe gjaku ose përbërës me origjinë bimore.

Të gjitha produktet e mishit të përpunuar kanë kaluar në një mënyrë ose tjetren trajtime të ndryshme fizike dhe kimike, të cilat i kanë siguruar produktit final jetëgjatësi, shije, ngjyrë më të mirë si dhe efikasitet në ruajtje dhe përdorim.

Procesi i trjtimit të mishit fillon nga :

- copëtim/prerje (në diametër të ndryshëm, varësisht prej produktit)

- kriposje,shtimi i aditivëve dhe i erëzave

- përzierje

- mbushje

- fermentim

- trajtim me nxehtesi

- tymosje (në produkte të caktuara) 


\subsubsection{MJETET E NEVOJSHME PER PERPUNIMIN E MISHIT}

Në teknologjin e përpunimit të mishit egzistojnë lloje të ndryshme të mjeteve që përdoren gjatë përpunimit të mishit. Disa nga paisjet bazë janë treguar në figurën 3.1.

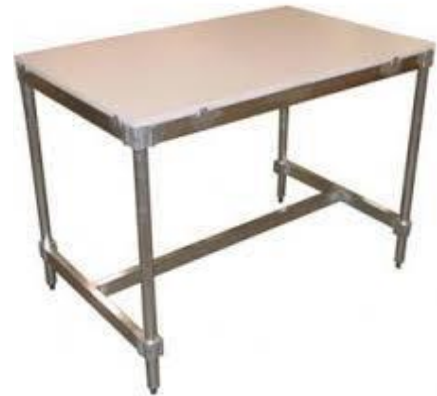

a) Tavolina për copëtim

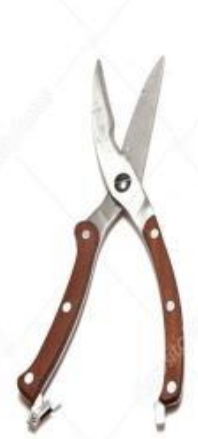

b) Thikat dhe gërshërët

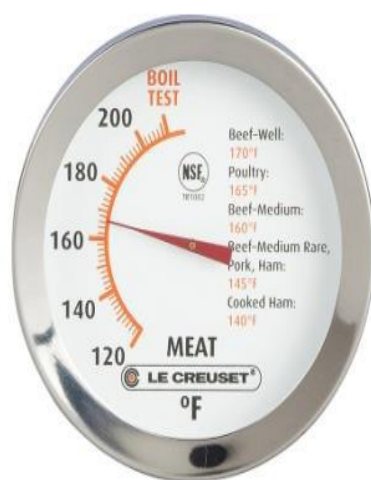

c) Termometër
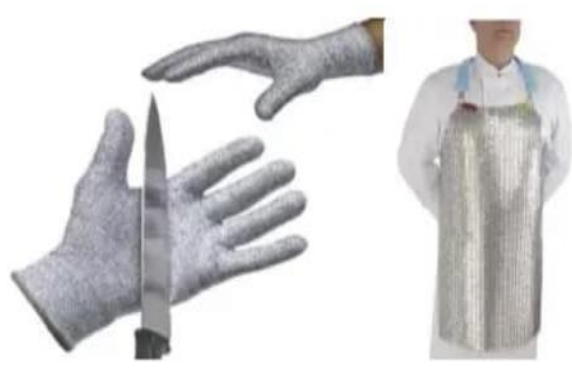

ç) Dorëzat dhe përparsja metalike

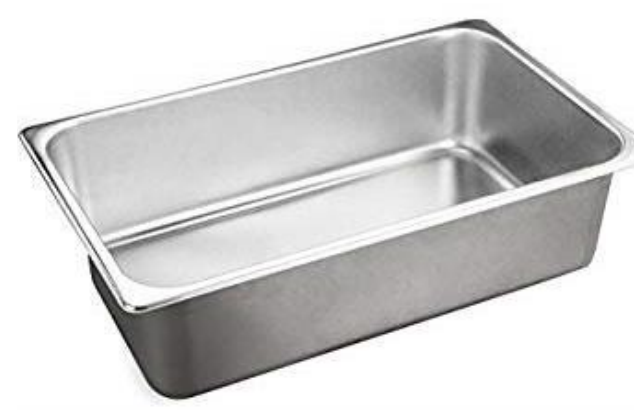

dh) Enë metalike për transport
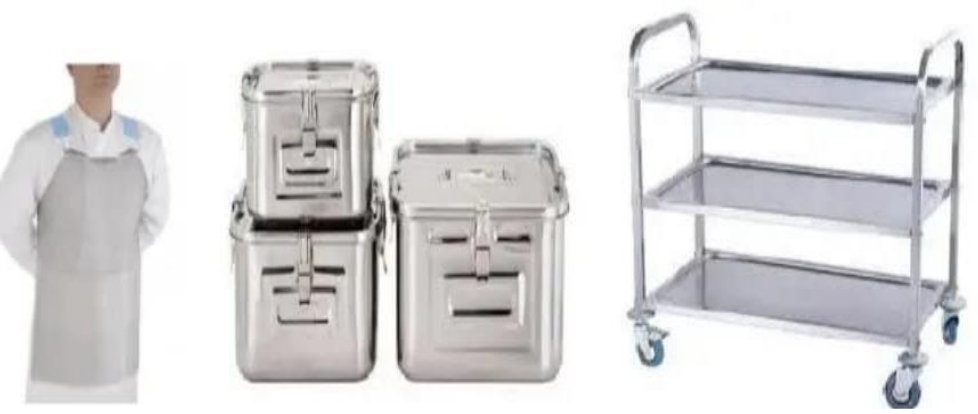

d) Tabakë metalik me sasi të vogël
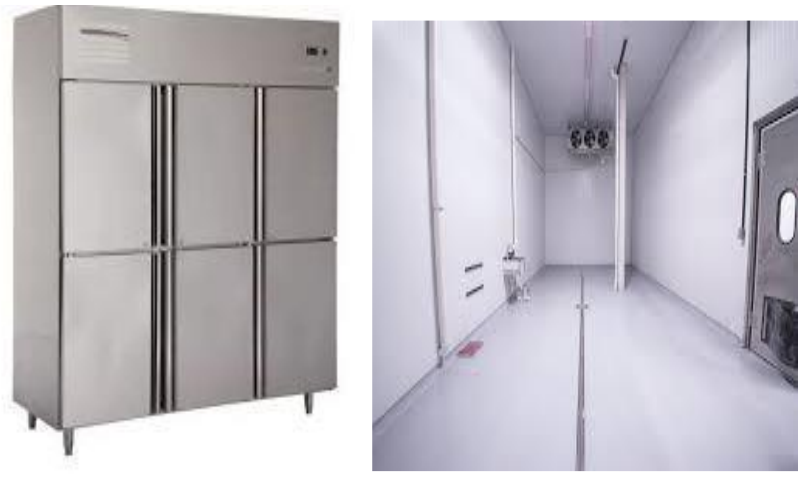

e) Frigorifer dhe dhoma statike frigoriferike

Figura 3.1 Paisjet bazë për punimin e mishit 
Tavolina për copëtimin e mishit. Tavolina përdoret për ndarjen e mishit në pjesë më të vogla dhe për coptimin e eshtrave. Ajo është e përshtatshme dhe e nevojshme në rast se mishi shitet i freskët dhe nuk kërkohet të bluhet. Shfrytëzohet shumë në mishtore të vogla tregtare, në restorante dhe nga industritë e mishit për coptimin e mishit me eshtra.

Thikat, gërshërët, çengelat. Thika dhe gërshërët janë paisje elementare në industrinë e përpunimit të mishit. Ato përdoren për largimin e mishit nga karkasa, për copëtimin e mishit, ndarjen e mishit nga eshtrat, largimin e dhjamit nga mishi etj. Ndërsa çengelat përdoren për varjen e copave (shpatull, kofsha,krahrori) të ndara të mishit gjatë punës apo vendosjes së mishit në dhomat frigoriferike.

Tabakat, enët metalike dhe troilerat. Tabakat përdoren për të mbajtur dhe transporuar sasi të vogla të lëndës së parë dhe për ti pastruar pjesët e makinave të tjera. Enët metalike përdoren për të mbajtur sasi të mëdha të lëndës së parë (deri në 200L). Ndërsa troilerat janë të lëvizshme për të mbajtur dhe transportuar lëndën e parë nga kuteri deri tek vendi i punës.

Kafazet dhe makinat e tymosjes. Kafazet e tymosjes kanë structure metalike, të cilat transportohen së bashku me produktin në proceset e mëtutjeshme (tymosje apo nxehje). Kafazet përbëhen edhe nga shkopinjët që mbajnë sallamet e varura, proshutat apo pjesët tjera të mishit për tharje, tymosje apo magazinim. Ndërsa makinat për tymosjen e mishit shfrytëzohen për tymosjen e prodhimeve me qëllim të konservimit të mishit dhe aromatizimit të tij. Tymosja i jep mishit karakteristika organoleptike mjaftë të shijshme dhe bënë që produktet të jenë mjaft të kërkuara në treg.

\subsubsection{SHTESAT KONSERVUESE DHE AROMATIZUESE}

Nga mishi mund të prodhohen lloje të ndryshme produktesh. Në këto produkte përveç mishit ujit dhe yndyrës që janë përbërësit bazë të tyre, shpesh here shtohen shtojca të cilat përmirësojnë pamjen e jashtme, shijen dhe qëndrueshmërinë e këtyre produkteve.

\section{KRIPA}

Kripa është një nga shtesat më të rëndësishme në përpunimin e mishit. Kripa përdoret për efektin e saj në shije dhe si agjent ruajtës apo konzervues. Sasia e kripës së shtuar varet nga lloji i produktit dhe veçanërisht nga përmbajtja e yndyrës, por në përgjithësi ajo varion nga 1.8 deri në $2.2 \%$ të përzierjes së produktit. Kripa nuk përdoret në sasi të mjaftueshme për të konservuar produktin, në këto sasi ajo ushtron veti antimikrobike, por për disa mikroorganizma kjo sasi nuk i pengon në aktivitetin e tyre ngase tolerojnë sasi shumë më të mëdha të kripës. 
Kripa kryen edhe funksione të tjera në prodhim. Ai shpërndahet në ujë dhe ndihmonë lidhjen e ujit dhe në kapacitetin emulsifikues të proteinave të mishit. Përdorimi i kripës si shtesë e vetme jep një produkt të thatë dhe të kripur i cili ka një ngjyrë jo tërheqëse, prandaj kripa zakonisht përdoret në kombinim me sheqerin dhe nitratet.

Mënyrat e kriposjes :

- Kriposja e terur (mishi, kripa dhe eventualisht shtesa të tjera përzihen në mes veti.)

- Kriposja e lagur (mishi vihet në shëllirë e cila është përzierje e ujit, kripës dhe lëndëve tjera ngjyruese.)

- Kriposja e shpejtë (uji i kripur injektohet në mënyrë të drejtpërdrejtë në muskulaturë ose në sistemin kardiovaskular të gjakut të copës së mishit.)

\section{SHEQERI}

Sheqeri i shtohet mishit si ndihmës për të balancuar shijen e kripur, për të dhënë aromë dhe për të shërbyer si një substrat për prodhimin e acidit bakterial në salçiçe të thata dhe gjysmë të thata. Sheqeri vepron me aminoacidet dhe ndikon në ngjyrën dhe aromën e produktit. Dekstroza dhe $\mathrm{d}$ glukoza përdoren në salçiçe në nivele prej $0.5 \%$ deri në $2.0 \%$. Gjithashtu edhe sakaroza dhe maltoza përdoren gjatë përpunimit të mishit. Sheqeri siguron që mishit mos t'i krijohen bakteret dhe myku.

\section{NITRITET}

Nitritet janë përdorur vazhdimisht për produktet e mishit e sidomos atë të sallameve, dhe akoma nuk është gjetur ndonjë substancë që mund t $\mathrm{i}$ zëvendësojë. Roli i nitriteve në mish është $i$ shumëfishtë si të stabilizojë ngjyrën e indit muskular, të kontribuojë në aromën karakteristike të mishitt të trajtuar, të pengojë rritjen e një numri mikroorganizmash dhe të vonojë zhvillimin e hidhërimit. Sot nitritet e përdorura në trajtimin e mishit përdoren në trajtën e nitritit të natriumit $\mathrm{i}$ cili pranohet gjerësisht tashmë si përgjegjës për konservimin, ngjyrën dhe aromën karakteristike të produkteve të mishit të trajtuar. Por është e rëndësishme që këto substanca te përdoren në sasi sa më të vogëla ,meqë ato në mish formojnë nitrozamina, të cilat rrezikojnë shëndetin e njeriut. EFSA (European Food Safety Authority) i klasifikon nitrozaminat si substanca kancerogjene.

Sasia maksimale e nitritit, e lejueshme në produktet e përfunduara të mishit, është zakonisht 200 ppm (pjesë për milion apo $\mathrm{mg} / \mathrm{kg}$ ), kjo vlerë mund të jetë edhe më e vogël varësisht prej llojit të produktit apo legjislacionit të vendit ku prodhohet apo tregtohet. 


\section{FOSFATET}

Fosfatet përdoren për të garantuar lagështinë në mishin e ftohur, pothuaj në të njëjtin nivel sikurse tek mishi pa kocka. Në disa shtete nuk lejohet përdorimi i fosfateve, ndërsa në disa të tjerë lejohet përdorimi vetëm kur provohet efekti teknologjik. Por nëse lejohet, duhet respektuar sasia $0.3-0.5$ \% në përzierjen e sallameve. Fosfatet prishin aktinomiozinën dhe e zbërthejnë në aktinë dhe miozinë, të cilat mund të treten nga kripa për të rritur aftësinë mbajtëse të ujit.

\section{ACIDI ASKORBIK (Vitamina C)}

Acidi askorbik dhe kripa e tij(Askorbati i Na) kontribojnë në zhvillimin e ngjyrës te mishi i përpunuar. Acidi askorbik është përdorur në përqendrim 0.03-0.05\%, ndërsa askorbati i Na është përdorur me përqendrim $0.07 \%$. Në rastet kur përdoren këto shtesa, fillimisht shtohet kripa e nitritit dhe pastaj acidi askorbik.

\section{EREZAT}

Erëzat paraqesin një koleksion të erëzave të bimëve . Termi erëza zakonisht i referohet erëzave natyrale , të marrura në formë të gjetheve, frutit,kërcellit apo farës të cilat janë pastruar, tharë dhe imtësuar,ato janë të rritura kryesisht në rajone tropikale dhe subtropikale, që përmbajnë substanca aromatike të cilat $\mathrm{i}$ shtohen mishit në etapa të ndryshme të përpunimit.Preferencat e erëzave ndryshojnë nga rajoni në rajon, në shumë raste edhe brenda të njëjtit vend. Këto preferenca duhet të merren parasysh nga çdo prodhues lokal, për shkak të ndikimit të tyre të drejtpërdrejtë në zakonet ushqimore dhe kërkesat e konsumatorëve.Llojet e erëzave që përdoren më së shumti janë:qepë, hudhër, piper i zi, piper i kuq, rozmarinë, kanellë, arrë muskati, xhenxhefil, origano,borzilok etj.

Erëzat veprojnë mbi gjëndrat e pështymës dhe ato gastrike, duke shtuar sekretimin, duke stimuluar oreksin dhe duke përmirësuar tretjen e mishit . Ka erëza, shija e të cilave mbetet e pandryshuar edhe mbas ekspozimit në temperaturë të lartë. Më pak rezistente janë piperi, rozmarina, origano etj.

\footnotetext{
AMIDONI

Amidoni përdoret në produktet e mishit si agjentë lidhës për ujin duke ndikuar në rritjen e rendimentit, zvogëlimin e humbjeve gjatë përpunimit, përmirësimin e strukturës, dhe rritjen e sasisë së përthithjes së ujit për të zgjatur qëndrueshmërinë. Amidoni shtohet në produkt deri në masen $4 \%$.
} 


\section{KULTURAT BAKTERIALE (STARTER KULTURAT)}

Kulturat starter që përdoren në prodhimin e produkteve të fermentuara të mishit janë të përfaqsuara nga bakteret laktike të cilat shtohen për të përmirsuar konsistencën dhe kontrollin e fermentimit. Shtamet të cilat shtohen në këto produkte përfaqsohen nga gjina Micrococcus ( të cilat janë të pranishme në masë të madhe që nga fillimi i procesit të maturimit deri në fund të tij), Staphylococcus (të cilat hidrolizojnë lipidet duke kontribouar në formimin e aromës bashkë me Micrococcus). Poashtu në një masë më të vogël edhe gjinia Laktobacillus është e pranishme kur fillon procesi i maturimit të tyre.

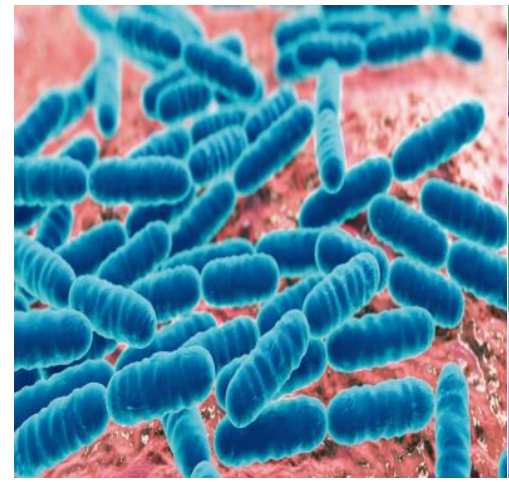

Laktobacillus

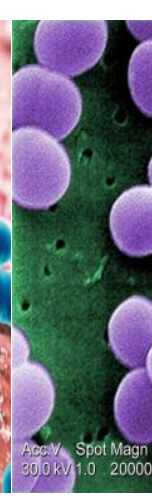

Staphylococcus

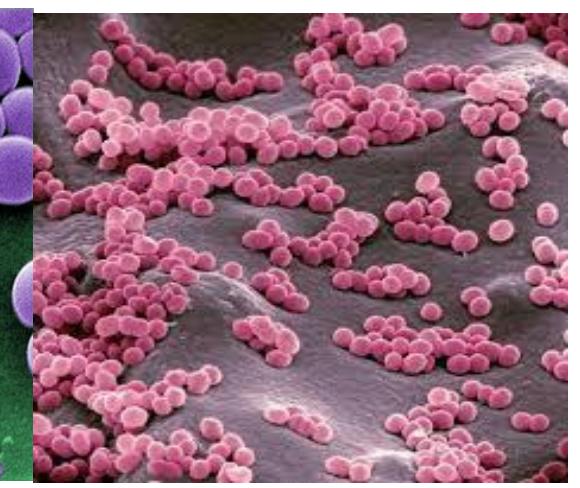

Micrococcus

Figura 3.2.Kulturat starter

\section{MBESHTJELLSIT NATYRAL DHE ARTIFICIAL}

Cipat mbështjellëse përbëjnë $10 \%$ të peshës totale të sallamit dhe janë dy lloje natyrale dhe artificial. Qëllimi I mbështjellëseve është dhënia e formës dhe mbrojtja e brumit nga faktorët e jashtëm. Zorrët natyrale që përdoren janë zakonisht pjesët e zorrëve të kafshëve, mukoza e ezofagut të gjedheve dhe derrave, ato fillimisht pastrohen dhe për qëllim ruajtje deri në momentin e përdotimit vendosen në $\mathrm{NaCl}$ të ngurtë me temperaturë $5^{\circ} \mathrm{C}$.

Zorrët artificiale prodhohen nga materialet të cilat nuk janë të dëmshme për shëndetin. Mbështjellësit e ngrënshëm prodhohen nga kolagjeni i cili përgatitet me tretjen e lëkurës me acid dhe duke ekstraktuar kolagjenin në një solucion të koncentruar të sulfatit të amoniumit. Këtij kolagjeni i shtohen komponime të ndryshme si celuloza dhe derivatet e saj, të cilat e bëjnë cipën e kolagjenit më të ngjashme me zorrët që përdoren si cipa natyrale. dhe materiale tjera të ngjashme të tretshme, mbështjellësit janë pjesë përbërse e prodhimit me të cilin konsumohet produkti dhe 
nuk shkaktojnë dëme në organizëm. Pamja, shija, aroma, ngjyra dhe konsistenca duhet të jenë të natyrshme për secilin lloj të sallameve.

\section{SHTESAT ME PREJARDHJE SHTAZORE}

Shtesat me prejardhje shtazore nuk përdoren vazhdimisht por mund të ndihmojnë në prodhimin e produkteve më specifike të mishit. Në përgjithësi ato kanë funksion lidhës të ujit ne produkt dhe pengojn ndarjen e yndyres gjatë trajtimit me nxehtësi. Shtesat që përdoren më shumë janë : kazeina e qumështit, qumësht pa yndyrë ose qumësht pluhur, gjelatinë, plazma e gjakut, vezë etj.

\subsection{AMBALAZHIMI I PRODUKTEVE TË MISHIT}

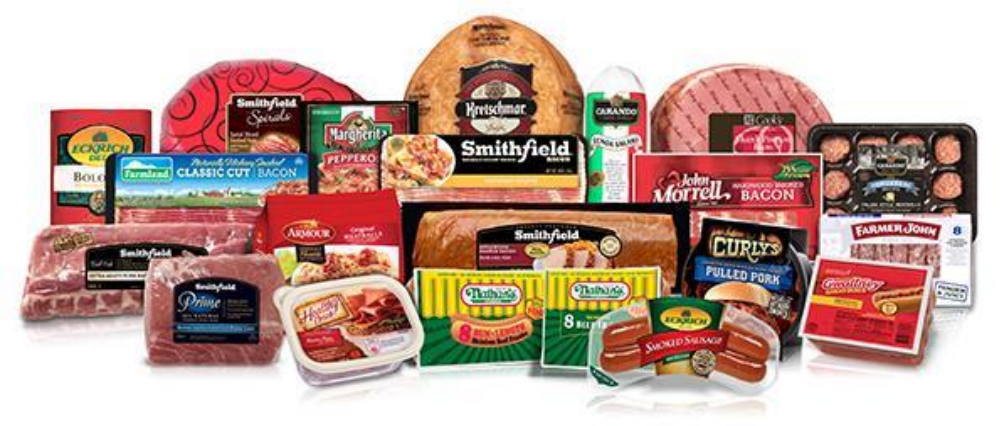

Figura 3.3. Produkte të ambalazhuara të mishit

Procesi i ruajtjes së mishit bazohet në ftohje dhe lloje të ndryshme të paketimit, të cilat ndikojnë në rritjen e afatit të përdorimit. Për shkak të përbërjes kimike dhe karakteristikave biologjike,mishi është një mjedis i favorshëm për rritjen e mikroorganizmave. Qëllimi i çdo sistemi paketimi për produkte të mishit është të parandalojë ose vonojë ndryshimet e padëshiruara në pamjen, aromën, erën dhe strukturën e mishit. Mosruajtja e këtyre cilësive mund të rezultojë në humbje ekonomike për arsye se konsumatori nuk do të dëshiroj ta blej atë produkt. Prandaj, një paketim ruajtës duhet të pengojë në mënyrë ideale aktivitetet e padëshiruara të enzimeve, por të mos ndërhyjë ose të mos bashkveproj në aspektin kimik me produktin e ambalazhuar. 


\subsubsection{LLOJET E AMBALAZHIMIT TË PRODUKTEVE TË MISHIT}

Ambalazhet që përdoren për mishin dhe prodhimet e mishit janë kryesisht polietilene.

Ato janë qese të cilat mbështjellin produktin në të gjithë sipërfaqen e tij. Kjo mbështjellje kryhet nëpërmjet makinerive të posaçme që cilat bëjnë largimin e ajrit. Shumë lloje sallamesh dhe proshutash ambalazhohen në atmosferë të modifikuar, proces i cili realizohet në dhoma biologjikisht të pastra. Gjithashtu, edhe ruajtja e këtyre produkteve duhet të kryhet në temperaturë të ulët, duke reduktuar mundësinë e prishjes së tyre nën veprimin e mikroorganizmave të hyrë gjatë procesit të ambalazhimit. Meqenëse oksigjeni shkakton ç'ngjyrim të këtyre produkteve ato ambalazhohen në një atmosferë të modifikuar që përmban N2 apo CO2, ose të kombinuara. Zakonisht, ambalazhet janë në formë tabakaje të cekëta (kombinime të polimerëve të ndryshëm) të mbuluara me një shtresë filmi plastik.

Llojet e paketimit janë : paketimi në atmosferë të modifikuar dhe paketimi nën vakum .

Paketimi në atmosferë të modifikuar bazohet në modifikimin e përbërjes së gazit në kontakt me ushqimin duke zëvendësuar ajrin me një gaz të vetëm ose një përzierje gazesh . Ky lloj paketimi e ruan ngjyrën e dëshirueshme të kuqe të ndritshme të mishit. Përzierja më e zakonshme e gazit është 60-80\% O2 dhe 20-30\% CO2 .Gazrat tjera të cilat përdoren janë N2, O2 dhe CO2. Zgjedhja e gazit që përdoret ose kombinimit të gazrave varet nga produkti i paketuar.

CO2 është i pranishëm në atmosferë në një nivel të ulët (0.03\%). CO2 është një gaz pa ngjyrë me një erë të lehtë të butë në nivele të larta. Tretësira e $\mathrm{CO} 2$ në ujë dhe fazat e lipideve të produktit rritet me uljen e temperaturës . Për këtë arsye, aktiviteti antimikrobik i CO2 është dukshëm më i madh në temperatura nën $7{ }^{\circ} \mathrm{C}$.

Paketimi nën vakum është një metodë tjetër që përdoret për ruajtjen e mishit me kosto më të ulët të paketimit. Paketimi me vakum zgjat kohën e ruajtjes së mishit edhe më gjatë se paketimi me atmosferë të modifikuar. Efektet kryesore të dëshirueshme të paketimi me vakum janë zvoglimi i aromave. Paketimi nën vakum ndikon që paketimi të tkurret fort rreth produktit, dhe rrjedhimisht kjo e rrit qëndrueshmërinë e mishit. Vitet e fundit, kjo teknologji e paketimit është rritur në mënyrë të konsiderueshme në vendet e industrializuara për shkak të kërkesës për një mish më të butë dhe me një afat të gjatë kohor gjatë shitjes me pakicë . 


\subsubsection{KUSHTET QË DUHET TË PLOTËSOI MATERIALI PËR AMBALAZHIM}

Materialet për ambalazhim duhet të jenë materiale me përbërje të njohur, dhe të jenë të lejuara me ligj.

Materiali për ambalazhim duhet poashtu të plotësoj disa kushte të domosdoshme: Materiali për ambalazhim duhet të jetë i papërshkrueshëm nga uji, ajri dhe erërave të këqija ,duhet të jetë rezistent ndaj temperaturave të ulëta dhe të larta, sepse produkti mund ti nënshtrohet ngrirjes dhe më pas shkrirjes ,të jetë rezistentë ndaj acideve organike të pranishme në produkt,të ketë shpejtësi dhe prakticitet në procesin e ambalazhimit.

Ajo që është shumë e rëndësishme dhe që duhet theksuar është që materiali ambalazhues nuk duhet të bashkëveprojë me produktin pasi do të kemi shkëmbimin e lëndëve të materialit në produkt dhe ky proces do ta kthente këtë të fundit në toksik për konsumatorin. 


\section{METODOLOGJIA E HULUMTIMIT}

\subsection{QËLLIMI I HULUMTIMIT}

Qëllimi i hulumtimit është bërë mbi bazen e krijimit të njohurive substanciale të konsumit të prodhimeve të mishit në Kosovë. Ky hulumtim na tregon pasqyren se sa i njohin konsumatorët përbërjen e prodhimeve të mishit, sa e besojn tregun tonë të prodhimit, a i kushtojnë vëmendje udhëzimeve të ruajtjes apo datës së skadimit etj.

\subsection{OBJEKTIVAT E HULUMTIMIT}

Për të arritur qëllimin e hulumtimit kemi zgjedhur disa detyra:

- Të analizojmë dhe studiojmë trendin e të ushqyerit;

- Të hartojmë anketën (pyetësorin), si mjet hulumtimi;

- Të informohemi nga konsumatorët;

- Të grumbullojmë të dhëna nga konsumatorët;

- Të diskutojmë pasqyrën e fituar nga anketa.

\subsection{DETYRAT E HULUMTIMIT}

Në mënyrë që hulumtimi të jetë sa më produktiv dhe efikas në atë që kërkojmë, këmi caktuar disa detyra, si:

- Të organizohet veprimtaria kërkimore në sistemin e aplikimit të instrumenteve si mjete të hulumtimit për grumbullimin e opinionit mbi temën në fjalë;

- Prezantimi dhe paraqitja e të dhënave në mënyrë grafike;

- Interpretimi i rezultateve të hulumtimit.

\subsection{METODAT, TEKNIKAT DHE INSTRUMENTET E HULUMTIMIT}

Si metodë më të përshtatshme gjatë hulumtimit është aplikuar metoda e analizes teorike, induktivededuktive, observativo-deskriptuese, dhe metoda statestikore .

Si teknika të hulumtimit është përdorur anketimi, ndërsa si instrumentë është përdorur pyetësori. Të gjitha analizat statistikore janë punuar duke përdorur programin MS Excel.

\subsubsection{MOSTRA E HULUMTIMIT (POPULLACIONI)}

Zhvillimi i hulumtimit është kryer në formën “online”, në Kosovë.

Popullacioni i këtij hulumtimi janë qytetarët e Republikës së Kosovës, nga pothuajse të gjitha rajonet.

Numri i të anketuarve është 100 (njëqind). 


\subsubsection{PYETËSORI}

1. Sa keni njohuri për përmbajtjen e prodhimeve të mishit?

2. Cilat nga prodhimet e mishit i preferoni?

3. Sa keni besim në prodhimin e produkteve të mishit në Kosovë?

4. A ndikon çmimi më i lartë në besimin tuaj si produkt më i sigurtë?

5. Çka parapëlqeni në konsumin e këtyre produkteve?

6. A i kushtoni rëndësi udhëzimeve të ruajtjes të shënuara në ambalazh?

7. Sa jeni të vëmendshëm sa i përket datës së skadimit gjatë blerjes?

8. Sa herë në jave konsumoni produkte të mishit?

9. A ka rëndësi origjina e produktit në përzgjedhjen tuaj?

10. A e keni menduar ndonjëherë të ndaloni konsumin e mishit ?, të bëheni vegjetarian apo vegan? 


\section{PREZANTIMI DHE ANALIZA E REZULTATEVE}

\section{CILAT PRODUKTE TË MISHIT I PREFERONI?}

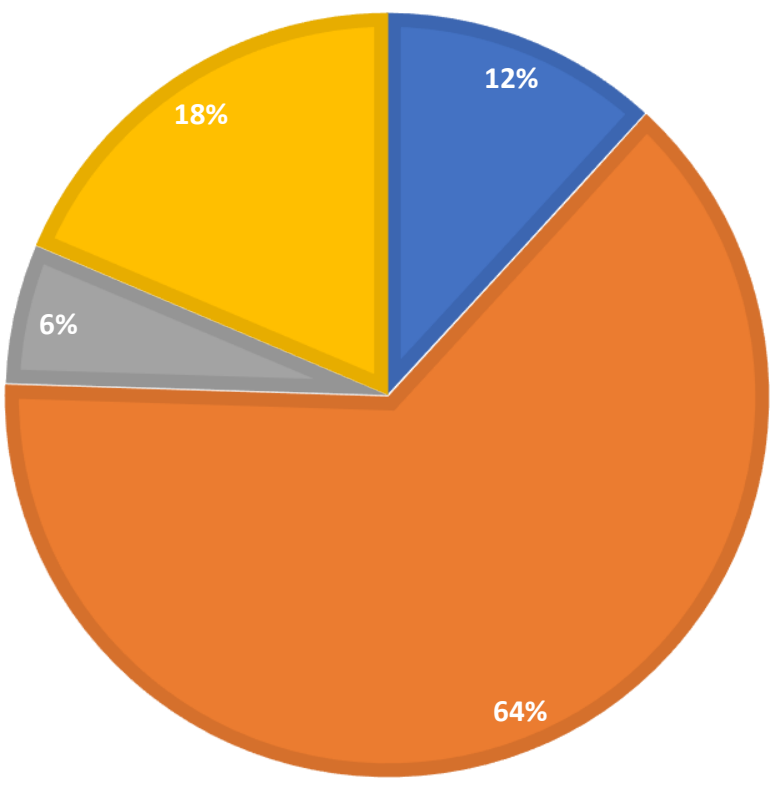

- Sallamet/Salçiçet

- Produktet e tymosura/thara

Konservat e mishit

Suxhukun

\section{SA HERË NË JAVË KONSUMONI PRODUKTE TË MISHIT?}

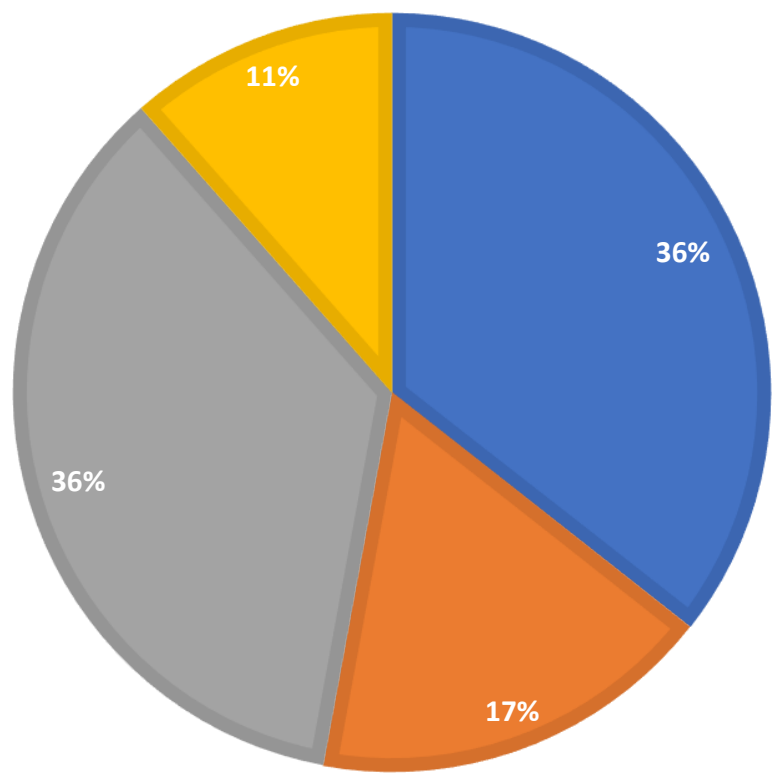

- Më pak se 3 herë

- Më shumë se 5 herë

4 herë në javë

nuk konsumoj asnjëherë 


\section{SA KENI NJOHURI PËR PËRMBAJTJEN E PRODUKTEVE TË MISHIT?}

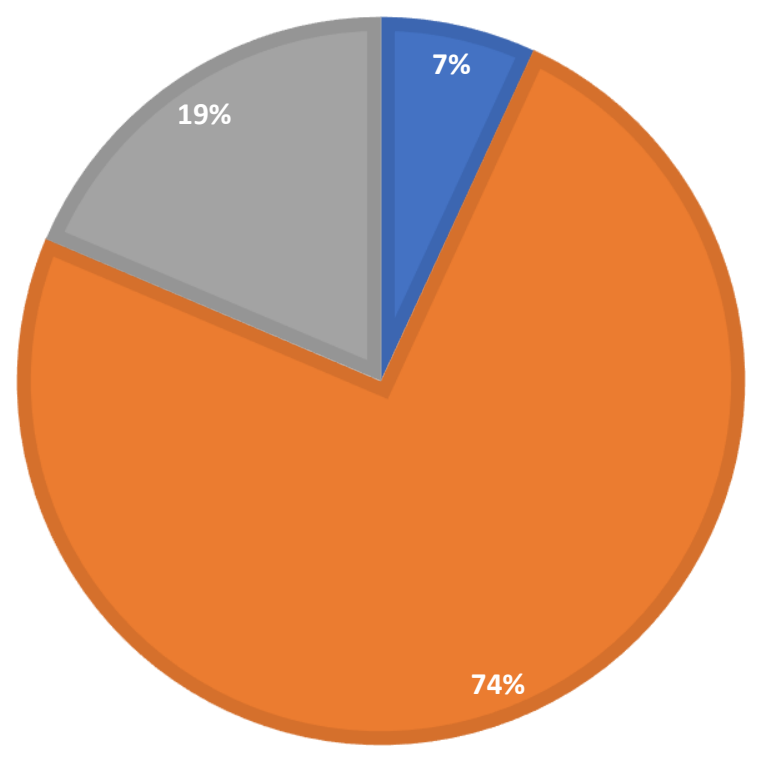

- Nuk kam

- Kam pak njohuri

Kam shumë njohuri

\section{SA KENI BESIM NË PRODHIMIN E PRODUKTEVE TË} MISHIT NË KOSOVË?

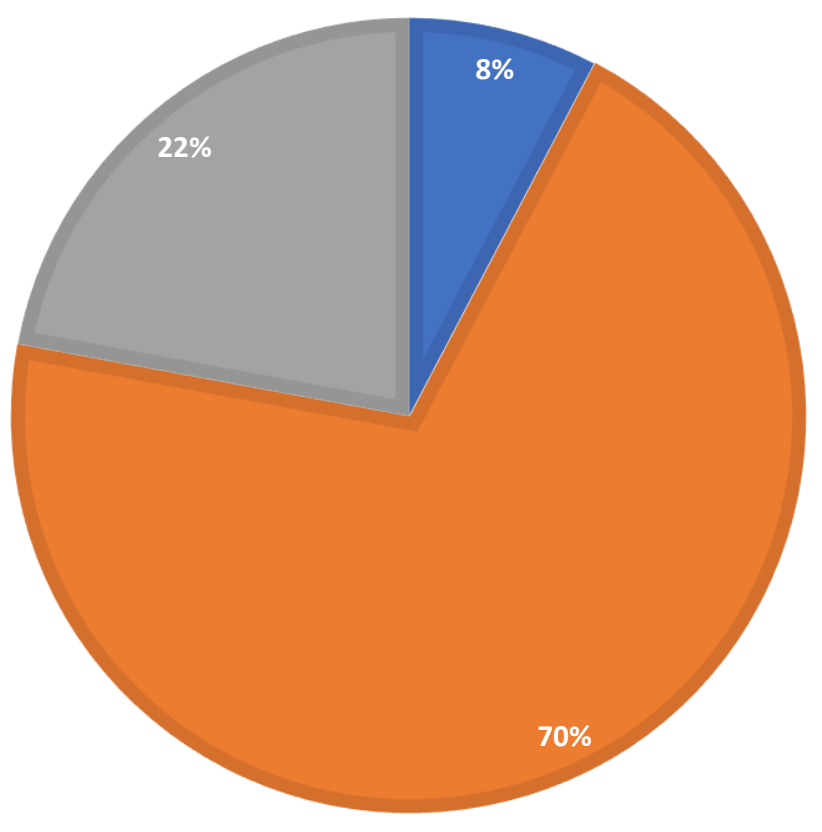

- Kam shumë besim në të gjitha industritë e mishit

- Kam besim në industri të caktuara

nuk kam besim aspak 


\section{A I KUSHTONI RËNDËSI UDHËZIMEVE TË RUAJTJES TË SHËNUARA NË AMBALAZH?}

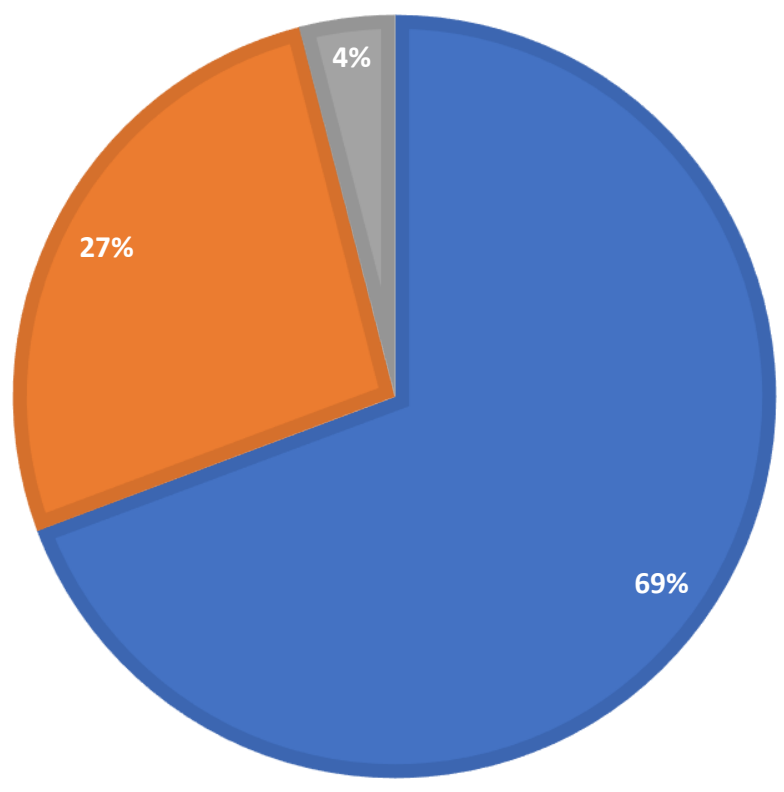

— l kushtoj gjithmonë rëndësi

— I kushtoj rëndësi vetëm pas hapjes së paketimit të produktit

nuk I kushtoj rëndësi asnjëherë

\section{SA JENI TË VËMENDSHËM SA I PËRKET DATËS SË SKADIMIT GJATË BLERJES?}

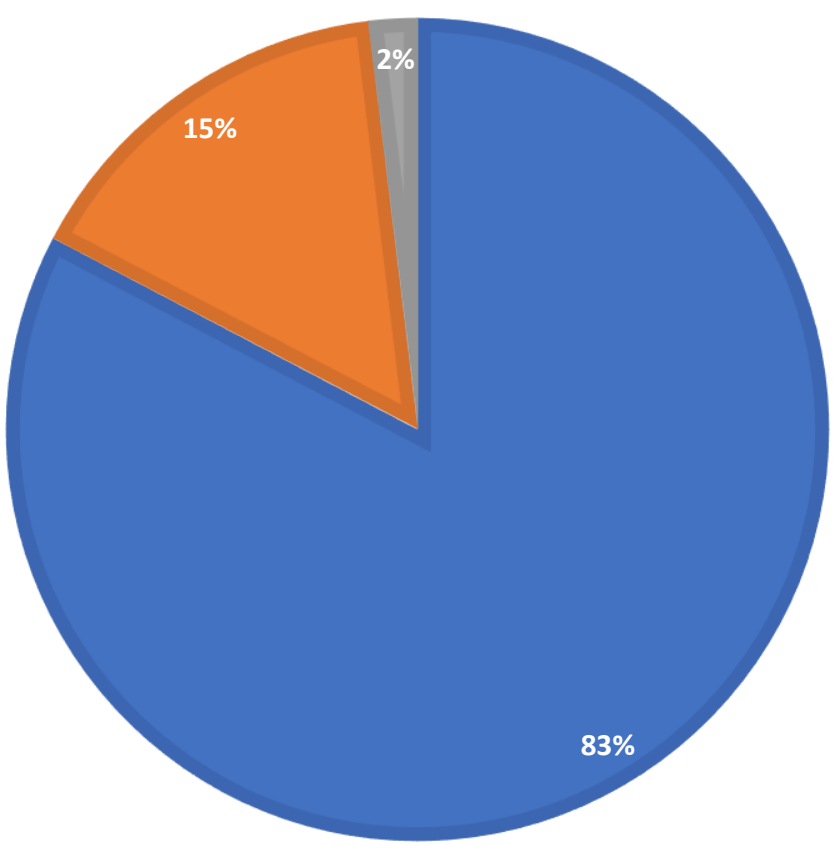

— Jam gjithmonë i/e vëmendshëm/e n Varësisht sa kam kohë për blerje nuk jam aspak i/e vëmendshëm/e 


\section{A NDIKON ÇMIMI MË I LARTË NË BESIMIN TUAJ SI PRODUKT MË I SIGURT?}

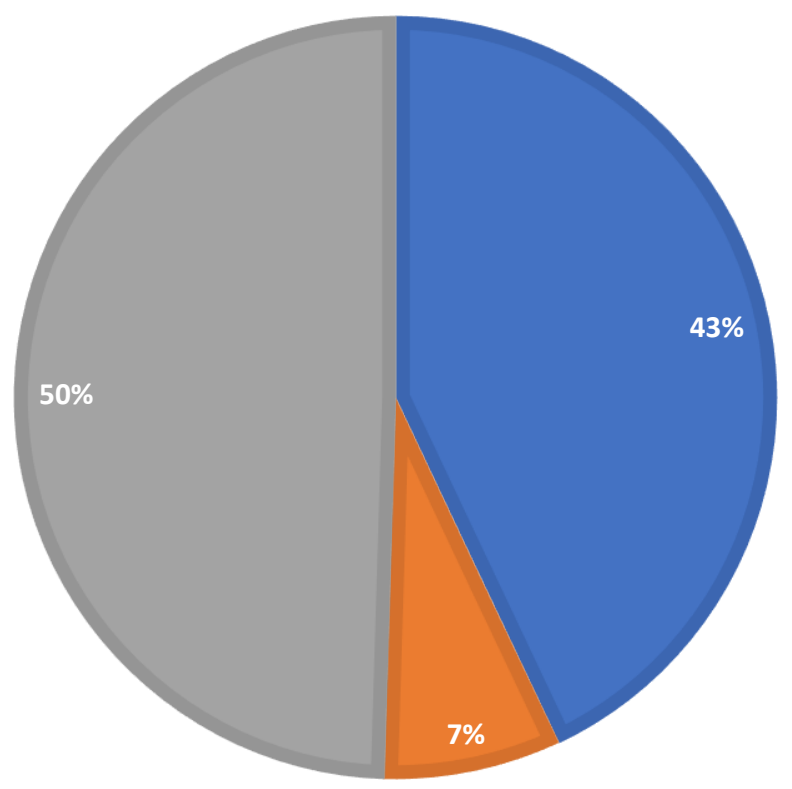

Do, ndikon

—Jo, nuk ndikon

ndikon , nganjëherë

\section{ÇKA PARAPËLQENI NË KONSUMIN E PRODUKTEVE TË MISHIT?}

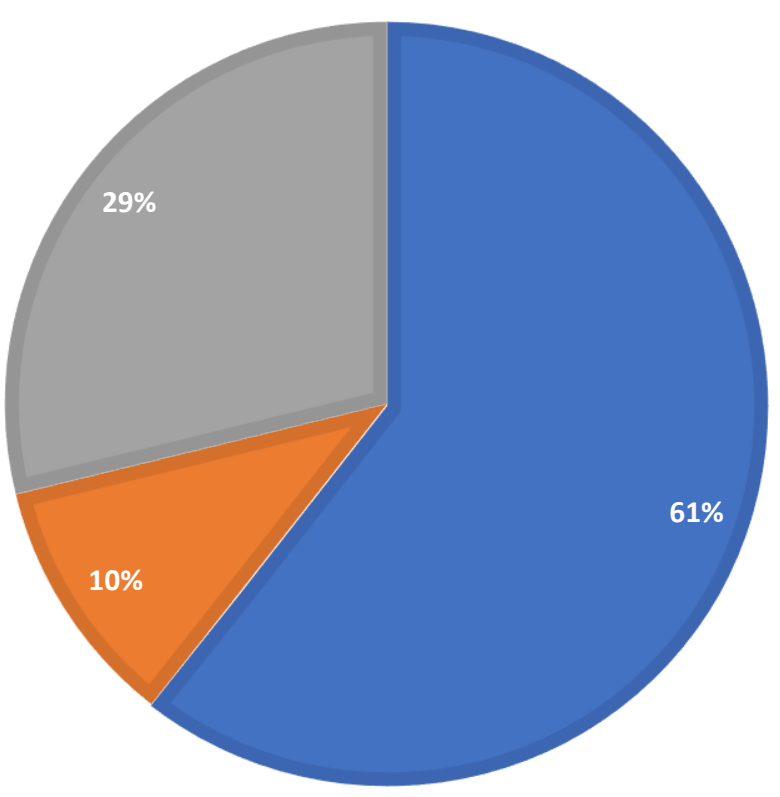

口 Shija

nërgaditja e shpejtë për konsum

E konsideroj produkt më energjetik për aktivitet ditor 


\section{A NDIKON ORIGJINA PRODUKTIT NË PËRZGJEDHJEN TUAJ?}

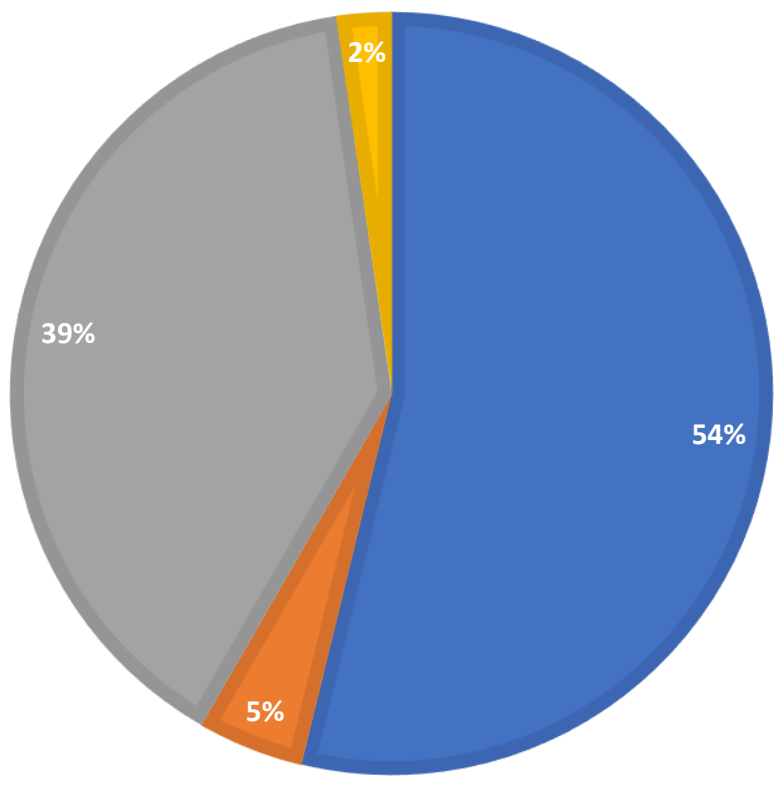

- Po

a Jo

- Preferoj prodhime vendore

- Kam besim më të madh në produktet e importuara

\section{A KENI MENDUAR NDONJËHERË TË NDALONI KONSUMIN E MISHIT?/ TË BËHENI VEGJETARIAN APO VEGAN?}

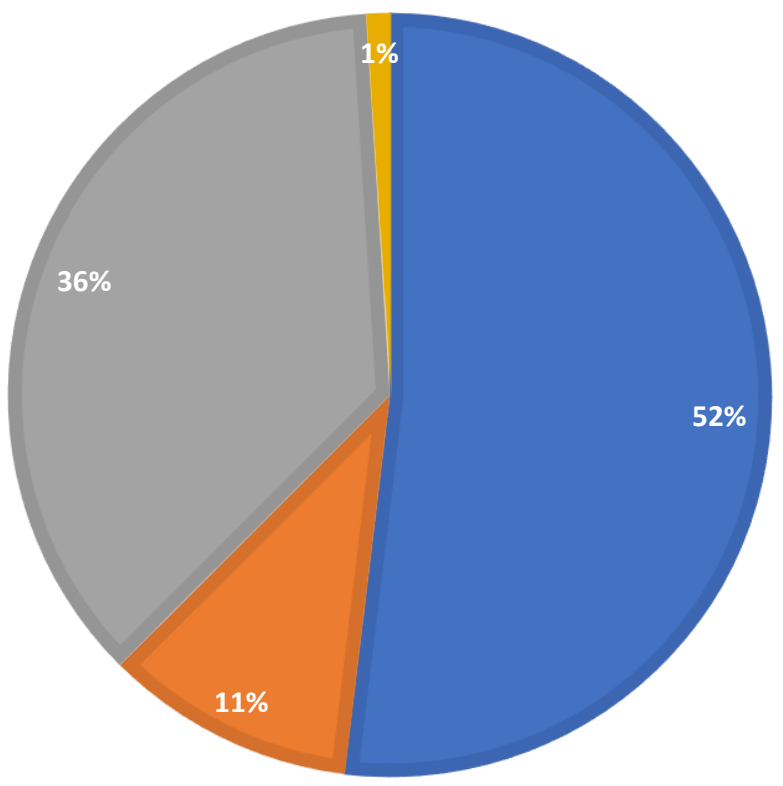

- Jo

- Po

Kam menduar ta reduktoj, por jo ta ndaloj

Unë nuk konsumoj mish 


\section{KONKLUZIONE DHE REKOMANDIME}

Struktura e industrisë së mishit ka ndryshuar në mënyrë dramatike me kalimin e kohës, veçanërisht në segmentet e paketimit dhe të ushqyerit e kafshëve të destinuara për therrje. Ky ndryshim ka ardhur si pasojë e dinamizimit të tregut që kërkon nga prodhuesi të minimizojnë kostot e prodhimit ndërsa, në të njëjtën kohë të ruaj e të përmirësoj cilësinë.

Zbatimi i teknologjisë ka luajtur gjithashtu një rol të madh në rritjen e shumëllojshmërisë së produkteve të reja dhe rritjen e efikasitetit të prodhimit.

Higjiena e mishit është një fushë e ndërlikuar dhe shumë e rëndësishme,ajo bazohet në rregulloret nga autoritetet kompetente dhe programet ose rregullat e higjienës së brendshme të vendprodhimeve të mishit.

Konsumi i mishit për person është rritur afërsisht 20 kilogram që nga viti 1961, një person mesatarisht konsumon rreth 43 kilogramë mish,disa studime tregojnë se bujqësia tradicionale e rritjes së kafshëve për therrje ka kosto të lartë, krahasuar me përfitimet.Kjo ka bërë që të hulumtohen edhe mënyra tjera sic është prodhimi i mishit sintetik.

Në bazë të hulumtimit të bërë kemi kuptuar, se pjesa më e madhe e konsumatorve kanë pak njohuri mbi përmbajten e produkteve të mishit por, megjithatë konsumi i tyre është në një nivel mjaft të lartë dhe arsyeja e kësaj dukurie nga anketa ka rezultuar se konsumatorët i pëlqejnë këto produkte për nga shija , por duke mos anashkaluar vlerat ushqyese dhe mundësia e shpejtë e gatimit të tyre. Edhe pse konsumatorët nuk kanë besim të plotë në industrit e mishit në Kosovë, në pyetjen se "Sa ka rëndësi origjina e produktit?”, ata janë përgjigjur duke pohuar se ka shumë rëndësi dhe në masë të madhe i preferojnë prodhimet vendore. Poashtu pozitive ,ka rezultuar se produktet me çmim më të lartë, fitojnë besim më lehtë tek konsumatorët në aspektin e sigurisë së produktit.

Konsumatorët, kanë rezultuar se janë të vëmendshëm në kontrollimin e datës së skadimit gjatë blerjes, dhe se i kushtojnë rëndësi ruajtjes sipas udhëzimeve.

Edhe pse viteve të fundit po jetojmë me trendin e të ushqyerit shëndetshëm, në Kosovë të anketuarit janë shprehur me mbi 50\% se nuk e kanë menduar ndonjëherë që ta privojnë veten e tyre nga konsumi i prodhimeve të mishit.

Pasi që Kosova pikë kryesore të zhvillimit të ekonomisë e ka bujqësinë dhe blegtorinë, rekomandoj që industritë e mishit lëndën e parë për prodhim ta marrin në Kosovë dhe jo të importuar. Kjo përveç që na mundëson zhvillim të ekonomisë poashtu na siguron edhe prodhime më të sigurta për konsum. Besimi i qytetarëve të fitohet përmes inspektimeve më të shpeshta nëpër industri dhe 
thertore, si dhe industritë ti kushtojnë vëmendje të veçantë etiketimit, deklarimit real të përbërsve dhe sasis së përbërsve. 


\section{REFERENCAT:}

1.Ahmad S.R., Imran A. Hussain B.M. (2018). Nutritional Composition of Meat Meat Science and Nutrition.

2.Bijo, B. (2007). Higjena e mishit dhe e thertoreve.

3.Bijo, B. (2011). Teknologjia e perpunimit te mishit.

4.Biesalski H.K. (2005). Meat Science 70:509 [PMID: 22063749].

5.Bender A. E. (1992). FAO Food Nutr Pap. 53:1 [PMID: 1300286].

6.CODE OF HYGIENIC PRACTICE FOR MEAT (2005).CAC/RCP 58-2005.

7.FAO/WHO (2003c). The Recommended International Code of Practice General Principles of Food Hygiene CAC/RCP 1 -1969, Revision 4.

8.Kausar T., Hanan E., Ayob O., Praween B. Azad Z. (2019). A review on functional ingredients in red meat products. Bioinformation 15(5): 358-363.

9.Kumar V et al. (2010). Int. J. Food Sci. Technol. 461:122

10.Laranjo M., Talon R., Lauková A., Fraqueza J.M., Elias M. (2017). Traditional Meat Products: Improvement of Quality and Safety. Hindawi. Journal of Food Quality.

11.Ledward, D. (n.d.). Lawrie's meat science. Emeritus profesor of Food Science University of Reading.

12.Mestani, M. (2017). Teknologjia e perpunimit te mishit.

13.Meat procesing technology- Gunter Heinz Peter Hautzinger (2007).Food and Agriculture of the United Nations Regional office for Asia and the Pacific Bangkok.

14.Ranken, M. (2000). Meat and product technology.

15.Serrano A. et al. (2007). Trends Food Sci Technology. 12:401.

16.Williams,P. G.(2007).Nutritional composition of red meat .https://ro.uow.edu.au/hbspapers/48 